\title{
PRIORITY FACTORS IN THE DEVELOPMENT OF SUSTAINABLE OYSTER MUSHROOM AGRIBUSINESS
}

\author{
Novira Kusrini*)1, Rini Sulistiawati**), and Imelda*) \\ *) Faculty of Agriculture, Tanjungpura University \\ Prof. Dr. Hadari Nawawi Street, Pontianak 78124 \\ **) Faculty of Economics and Management, Tanjungpura University \\ Prof. Dr. Hadari Nawawi Street, Pontianak 78124
}

\begin{abstract}
Determining factors in the development of sustainable oyster mushroom agribusiness is an important issue presently considering oyster mushrooms have good opportunities and potential. This research aims to identify prioritizing factors in the development of sustainable oyster mushroom agribusiness in Kubu Raya Regency West Kalimantan Province. This research uses the descriptive method. Respondents were 30 key informants from related agencies (Agriculture Office of Food Crops and Horticulture, agricultural extension workers, researchers in horticulture, oyster mushroom entrepreneurs, and oyster mushroom traders). The research was conducted from March to June 2018. Data were analyzed by the Analytical Hierarchy Process (AHP) analysis. The result indicates that supporting facilities aspect is the most important criterion to be considered. The main sub-criteria are oil palm empty fruit bunches (OPEFB) potential (ecology), return on investment (financial), perception and attitudes of the community in consuming oyster mushrooms (socio-culture), capital (institution), labor availability (human resources), adoption readiness (technology), and market (supporting facilities). The main subsub criterion is market demand.
\end{abstract}

Keywords: AHP, market demand, oil palm empty fruit bunches, supporting facilities

\begin{abstract}
Abstrak: Penentuan faktor-faktor dalam pengembangan agribisnis jamur tiram berkelanjutan merupakan isu yang penting saat ini mengingat jamur tiram memiliki peluang dan potensi yang baik untuk dikembangkan. Penelitian ini bertujuan untuk mengidentifikasi dan memprioritaskan faktor-faktor dalam pengembangan usaha agribisnis jamur tiram berkelanjutan di Kabupaten Kubu Raya Provinsi Kalimantan Barat. Metode penelitian yaitu metode deskriptif. Responden yaitu key informan berjumlah 30 orang yaitu pihak instansi terkait (Dinas Pertanian Tanaman Pangan dan Hortikultura, penyuluh pertanian, peneliti bidang hortikultura, pengusaha jamur tiram, dan pedagang pengumpul jamur tiram). Penelitian dilakukan bulan Maret sampai Juni 2018. Analisis data menggunakan Analytical Hierarchy Process (AHP). Hasil mengindikasikan bahwaaspeksaranapenunjangadalahkriteriautamayang paling penting untukdipertimbangkan. Sub-kriteria utama yaitu potensi tandan kosong kelapa sawit (ekologi), tingkat pengembalian investasi (finansial), persepsi dan sikap masyarakat dalam mengkonsumsi jamur tiram (sosial budaya), kelembagaan permodalan (kelembagaan), ketersediaan tenaga kerja (sumber daya manusia), kesiapan adopsi teknologi (teknologi), pasar (sarana penunjang). Sub-sub kriteria utama yaitu permintaan pasar.
\end{abstract}

Kata kunci: AHP, tandan kosong kelapa sawit, sarana penunjang, permintaan pasar

\footnotetext{
${ }^{1}$ Corresponding author:

Email: novira_k@yahoo.co.id
} 


\section{INTRODUCTION}

Indonesia is one of the countries producing horticultural crops with the main commodities such as cabbages, shallots, potatoes, red peppers, and cayenne peppers. The high demand for horticultural products is due to the majority of Indonesian consume vegetables $(97.29 \%)$ and 3 out of 4 people consume fruits (BPS, 2017). Furthermore, the data shows that the average consumption of Indonesian horticultural products is 70 grams/ person/day for vegetable consumption and 38.8 grams/person/day for fruit consumption (Hermina and Prihatini, 2016).

Mushrooms are popular horticultural products for Indonesian because they taste delicious, have beneficial nutritional content for body health, and act as an alternative herbal treatment. The nutritional values in 100 grams of oyster mushrooms are $19-35 \%$ protein, $1.7-2.2 \%$ fat, carbohydrates, vitamin $\mathrm{B}$, vitamin $\mathrm{D}$, vitamin C, and minerals (Sumarni, 2006). Mushroom products are one of Indonesia's export products with total exports of $273,331 \mathrm{~kg}$ in 2016 and FOB value of US\$ 1,153,182 (BPS, 2016). Mushroom consumption in 2013-2017 increased by 3.96\%, while the progress of mushroom availability only reached $3.58 \%$ (Pusdatin, 2017). Thus, it opens an opportunity for farmers to create mushroom cultivation businesses.

Oyster mushrooms are one of the potentially-developed mushroom commodities because of the easily obtained spawns, relatively easy maintenance, and reasonably highmushroom selling price. Oystermushroom products can be consumed in the form of foodstuff or processed into mushroom chips. Oyster mushroom agribusiness has promising potential because it can provide optimal benefits for oyster mushroom cultivators and processed oyster mushroom entrepreneurs (Pramudya and Cahyadinata, 2012; Candra et al. 2014). In addition, oyster mushroom agribusiness can be organized with low costs and technology easily adopted and implemented by the business actors (Chioza and Ohga, 2014).

The implementation of oyster mushroom agribusiness in Indonesia requires strengthening the adoption of cultivation technology and post-harvest processing, institution strengthening, management optimization, and the use of production factors (Mabuza et al. 2012; Iriantinah, 2014; $\mathrm{Li}$ and $\mathrm{Hu}, 2014$; Febrianda and Tokuda, 2017). Farmers' willingness to starting oyster mushroom agribusiness is influenced by marital status, formal education, farmer group membership, mushroom consumption level, market availability, farming experience, and land area (Ongoche et al. 2017).

One of the main factors to be considered in the oyster mushroom cultivation is the use of the right growing media to increase the productivity of the oyster mushroom business. Mushroom growing media must contain carbohydrates (source C) and protein (source $\mathrm{N})$ to support the optimal growth and development of mushrooms (Sumiati and Shopa, 2009). Several types of mushroom growing media proven to provide optimal production results include sawdust, bagasse, rice straw waste, rice bran, corn flour, and agricultural lime (Sutarman, 2012; Maulidina et al. 2015; Setyaningsih et al. 2015; Rahmawati et al. 2016).

In West Kalimantan, one of the mushroom growing media that can be used for oyster mushroom cultivation is the oil palm empty fruit bunches (OPEFB). OPEFB has abundant availability due to the vast oil palm area of 1,055,656 ha of large plantations and 407,410 ha of smallholder plantations in 2016 (BPS, 2017b). The use of OPEFB as the growing media and a mixture of several additional ingredients can provide optimal growth of mushroom production (Hidayati et al. 2015; Purindraswari et al. 2016). Oyster mushroom agribusiness using OPEFB as the growing media is also feasible to be cultivated and can provide benefits for oyster mushroom entrepreneurs (Sulistiawati et al. 2017).

Some researches related to the development strategy for oyster mushroom agribusiness have been carried out by researchers (Iriantinah, 2014; Li and Hu, 2014; Dimyati and Astarina, 2016; Fatria, 2017; Febrianda and Tokuda, 2017; Ongoche et al. 2017). The purpose of this research is to determine priority factors in the development of sustainable oyster mushroom agribusiness with OPEFB as the growing media. The novelty of the research is the development of sustainable oyster mushrooms agribusiness that was conducted in this study using OPEFB as a growing media. The location of this study is in Kubu Raya Regency, West Kalimantan Province with the consideration that many $\mathrm{CPO}$ factories in this location. Therefore, the availability of OPEFB is abundance and then utilized by the local community as an oyster mushroom growing media. 


\section{METHODS}

This research uses the descriptive method by collecting data, testing hypotheses, and finding answers for research problems (Kuncoro, 2003). The research was conducted in Kubu Raya Regency from March to June 2018. Data sources were from primary and secondary data. Primary data was obtained from the interviews results with key informants related to criteria determination and alternative factor formulation. Secondary data was obtained from relevant agencies such as Statistics Indonesia, the Agriculture Office of Food Crops and Horticulture, and other literature. Determination of the key informants was through purposive sampling based on their expertise (Sekaran and Bougie, 2010), i.e. 30 respondents from the related agencies (Agriculture Office of Food Crops and Horticulture, agricultural extension workers, researchers in horticulture, oyster mushroom entrepreneurs, and oyster mushroom traders).

Data were analyzed used AHP (Analytic Hierarchy Process). AHP analysis stages include: 1) the components explanation in building a hierarchical model. The model formulation is constructed as comprehensive as possible to meet all the possibilities in the priority factor. The hierarchy model is classified into 4 levels (Figure 1). The level is the overall goal of the model. Level 2 is the main criteria for achieving goals, level 3 is sub-sub criteria, and level 4 is subsub criteria for ecology, financial, socio-culture, human resources, and supporting facilities criteria. The goal of this model is the formulation of the prioritizing factors in the development of oyster mushroom agribusiness in Kubu Raya Regency West Kalimantan Province; 2) Calculation of the geometric mean. The collected data will be converted into a geometric mean for each compared pair. The geometric mean method is used to convert different values into a single value for each criterion, sub-criteria, and sub criteria; 3) Comparative judgment, which makes a judgment on the relative importance between the two criterias at a certain level in relation to the preceding level. This judgment is the core of AHP because it influences the priority of criteria. The results are then presented in the pairwise comparison matrix; 4) Determination of priorities. The eigenvector value can be determined from each pairwise comparison matrix to get the local priority. Because the pairwise comparison matrix is found at each level, global priority can be obtained by synthesizing local priorities; 5) Calculation of consistency ratio. AHP allows the judgment inconsistency by providing the consistency ratio in which $\mathrm{CR}>1$ is unacceptable inconsistent and $\mathrm{CR}<1$ is sufficiently consistent. Figure 1 illustrates the hierarchy process of AHP analysis; 6) Sensitivity analysis. The criteria importance depends on time (Saad, 2016). Through sensitivity analysis, decision makers can monitor the sustainability of the factors if there is a change in the level of importance which influences the weighting value.

\section{RESULT}

\section{Criteria Weights Determination in the Development of Oyster Mushroom Agribusiness in Kubu Raya Regency}

The results of the criteria weighting show the most important criteria sequence to be considered in the development of sustainable oyster mushroom agribusiness in Kubu Raya Regency are the supporting facilities criterion (a weight of 0.396), financial criterion (a weight of 0.232) and human resources criterion (a weight of 0.148 ), as shown in Table 1.

The supporting facilities criterion is the main priority to be considered in formulating the development of oyster mushroom agribusiness. The criterion includes marketing, road access, transportation, and communication networks which are important elements in the development of agricultural product businesses (Aji et al. 2014; Imelda et al. 2017). The key factor to optimize marketing activities is to create material, information, and financial flows between networks to produce maximum consumer satisfaction (Indrajit and Djokopranoto, 2003; Munizu, 2015). The quality and quantity of communication and transportation facilities also play an important role in agribusiness development (Copra and Meindl, 2004).

The second priority is the financial criterion which always becomes a consideration for decision makers in business (Saad et al. 2016; Azizi et al. 2015). This criterion includes the investment value, operating costs, return on investment, productivity, and mushrooms selling price. The third priority is the human resources criterion covering aspects of skills, education, and availability of human resources. Human resources criterion, as the key to the company success, greatly influences the organizational development (Amini et al. 2016; Chiang and Birtch, 2010). 


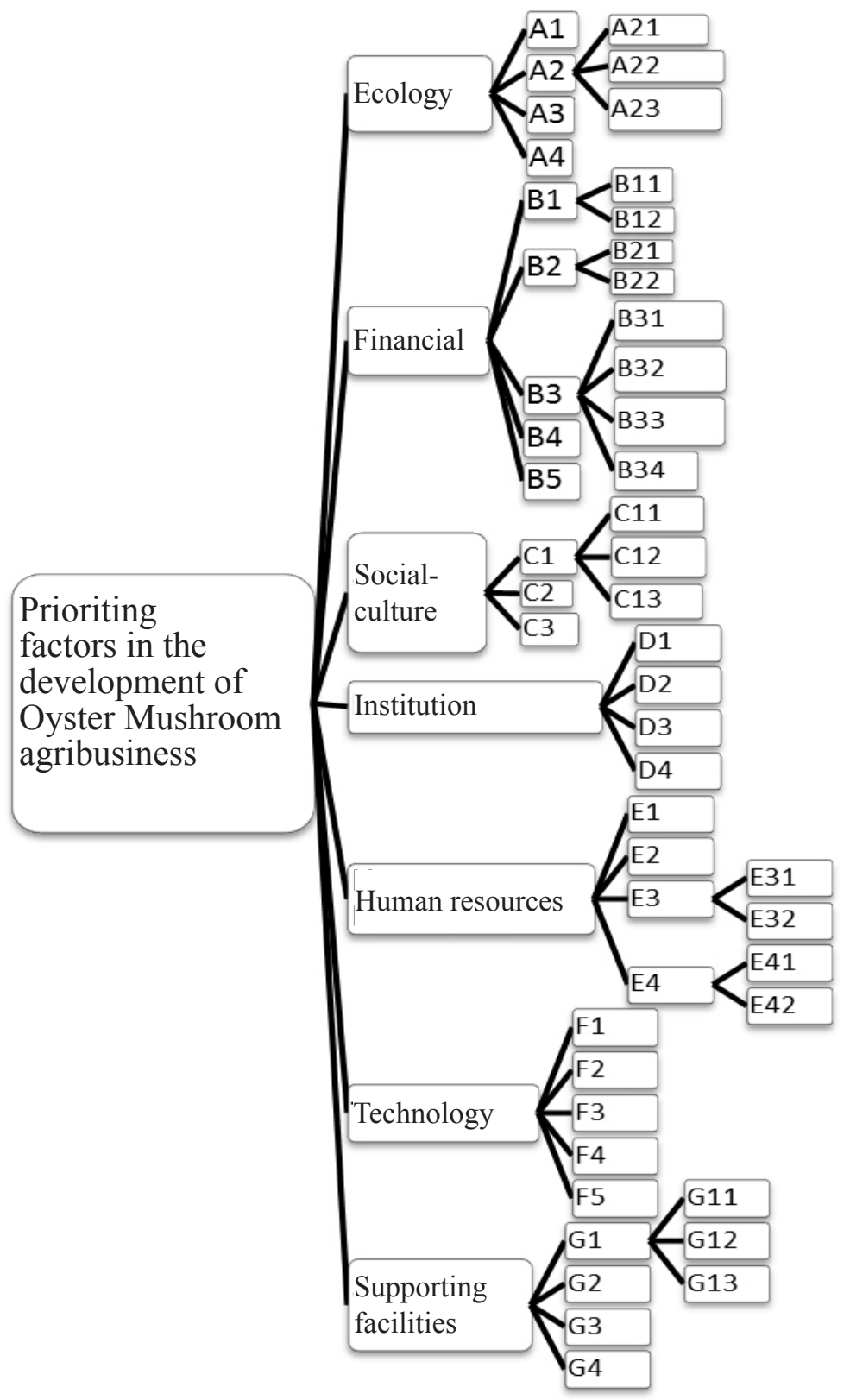

Description:

$\begin{array}{ll}\text { A1 } & \text { : OPEFB Potential } \\ \text { A2 } & \text { : Climatic Conditions } \\ \text { A21 } & \text { : Temperature } \\ \text { A22 } & \text { : Humidity } \\ \text { A23 } & \text { : Rainfall } \\ \text { A3 } & \text { : Potential pest attack } \\ \text { A4 } & \text { : Water source } \\ \text { B1 } & \text { : Investment value } \\ \text { B11 } & \text { : The price of supporting tools } \\ \text { B12 } & \text { : The price of supporting tools } \\ \text { B2 } & \text { : Operating costs } \\ \text { B21 } & \text { : Production input costs } \\ \text { B22 } & \text { : Labor costs } \\ \text { B3 } & \text { : Return on investment } \\ \text { B31 } & \text { : NPV } \\ \text { B32 } & \text { : Net B/C } \\ \text { B33 } & \text { : IRR }\end{array}$

$\begin{array}{ll}\text { B34 } & \text { : Payback Period } \\ \text { B4 } & \text { : Productivity } \\ \text { B5 } & \text { : Mushrooms selling price } \\ \text { C1 } & \text { : Perception } \\ \text { C11 } & \text { : Ease of implementation } \\ \text { C12 } & \text { : Suitability with needs } \\ \text { C13 } & \text { : Observability } \\ \text { C2 } & \text { : Mutual cooperation culture } \\ \text { C3 } & \text { : Local wisdom } \\ \text { D1 } & \text { : Capital } \\ \text { D2 } & \text { : Instruction } \\ \text { D3 } & \text { : Farmer group } \\ \text { D4 } & \text { : Farmer tools } \\ \text { E1 } & \text { : Labors skills } \\ \text { E2 } & \text { : Labors availability } \\ \text { E3 } & \text { : Education } \\ \text { E31 } & \text { : Formal }\end{array}$

$\begin{array}{ll}\text { E32 } & \text { : Informal } \\ \text { E4 } & \text { : Labors source } \\ \text { E41 } & \text { : From family } \\ \text { E42 } & \text { : Outside the family } \\ \text { F1 } & \text { : Post-harvest technology } \\ \text { F2 } & \text { : Adoption readiness } \\ \text { F3 } & \text { : Technology compatibility } \\ \text { F4 } & \text { : Cultivation technology } \\ \text { F5 } & \text { : Harvest technology } \\ \text { G1 } & \text { : Market } \\ \text { G11 } & \text { : Market demand } \\ \text { G12 } & \text { : Market distribution } \\ \text { G13 } & \text { : Market information } \\ \text { G2 } & \text { : Road access } \\ \text { G3 } & \text { : Means of transportation } \\ \text { G4 } & \text { : Means of communication }\end{array}$

Figure 1. Hierarchy model 
Table 1. Pair-wise comparison matrix: Main Criteria

\begin{tabular}{|c|c|c|c|c|c|c|c|c|}
\hline & Ecology & Financial & $\begin{array}{l}\text { Socio- } \\
\text { culture }\end{array}$ & Institution & $\begin{array}{l}\text { Human } \\
\text { Resources }\end{array}$ & Technology & $\begin{array}{l}\text { Supporting } \\
\text { facilities }\end{array}$ & $\begin{array}{c}\text { Priority } \\
\text { Vectors } \\
\text { (PV) }\end{array}$ \\
\hline Ecology & 1 & $1 / 3$ & 2 & 2 & $1 / 3$ & $1 / 3$ & $1 / 7$ & 0.056 \\
\hline Financial & 3 & 1 & 7 & 6 & 3 & 3 & $1 / 3$ & 0.232 \\
\hline $\begin{array}{l}\text { Socio- } \\
\text { culture }\end{array}$ & $1 / 2$ & $1 / 7$ & 1 & $1 / 3$ & $1 / 4$ & $1 / 4$ & $1 / 8$ & 0.029 \\
\hline Institution & $1 / 2$ & $1 / 6$ & 3 & 1 & $1 / 4$ & $1 / 3$ & $1 / 7$ & 0.043 \\
\hline $\begin{array}{l}\text { Human } \\
\text { Resources }\end{array}$ & 3 & $1 / 3$ & 4 & 4 & 1 & 3 & $1 / 3$ & 0.148 \\
\hline Technology & 3 & $1 / 3$ & 4 & 3 & $1 / 3$ & 1 & $1 / 5$ & 0.096 \\
\hline $\begin{array}{l}\text { Supporting } \\
\text { facilities }\end{array}$ & 7 & 3 & 8 & 7 & 3 & 5 & 1 & 0.396 \\
\hline Total & & & & & & & & $\mathrm{CR}=0.05$ \\
\hline
\end{tabular}

\section{Sub-Criteria Weights Determination in the Development of Oyster Mushroom Agribusiness in Kubu Raya Regency}

\section{Ecology Aspect}

In terms of the ecology aspect, the most important sub-criteria to consider are the OPEFB potential (a weight of 0.523), climatic conditions (a weight of 0.126 ), potential pest attack (a weight of 0.089) and water source (a weight of 0.261 ). The $\mathrm{CR}$ value of the ecology factors is $0.05(\mathrm{CR}<0.1)$. OPEFB potential becomes the most important consideration because of its abundant availability (Olisa and Kotingo, 2014). OPEFB utilization has not been handled optimally by most palm oil companies (Palamae et al. 2017), causing them to have a negative impact on the surrounding environment (Hendra et al. 2014). The use of OPEFB as the mushroom growing media has not been widely performed (Tabi et al. 2008; Hidayati et al. 2015; Kavitha et al. 2013). In West Kalimantan, 61 CPO factories produce OPEFB of 46,237.5 tons per hour (Kusrini et al. 2017). Thus, there is an OPEFB potential that can be used as the oyster mushroom growing media and as an effort to overcome environmental pollution.

\section{Financial Aspect}

In terms of the financial aspect, the most important subcriteria to be considered returns on investment (0.457), mushroom selling price (0.273), and investment value (0.151), operating costs (0.078) and productivity (0.041). The CR value of the economic factors is 0.06 $(\mathrm{CR}<0.1)$. Oyster mushroom cultivation business using
OPEFB requires a lot of capital for the manufacture of mushroom houses. Return on investment needs to be calculated as a consideration in making decisions to accept/reject a business plan or to stop/retain business which has been or is being implemented (Nurmalina et al. 2009; Kashmir and Jakfar, 2008).

\section{Socio-culture aspect}

In terms of the socio-culture aspect, the most important sub-criteria are the perception and attitudes of the community in consuming oyster mushrooms (0.648), mutual cooperation culture $(0.230)$, and local wisdom (0.122). The CR value of socio-cultural factors is $0.00352(\mathrm{CR}<0.1)$. Beliefs, values, attitudes, opinions, and people's lifestyles at the research location influence the demand for oyster mushrooms. People habit in snacks consumption will increase the production, market share, and customers.

Institution aspect

In terms of the institution aspects, the most important sub-criteria are capital institution (0.543), Alsintan (Agricultural Tools and Machines) institution (0.230), farmer group institution (0.136), and instruction institution (0.070). The $\mathrm{CR}$ value of the institutional factors is $0.06(\mathrm{CR}<0.1)$. To develop oyster mushroom agribusiness, adequate institutional support is needed, especially from the capital institution (Santosa and Marimin, 2001). The capital condition of mushroom entrepreneurs is still not sufficient and there is no assistance from the local government or related agencies. Most of the entrepreneurs' capital comes 
from their own capital, bank loans, and non-banking institutions. Therefore, there is a need for additional capital to increase the production capacity of white oyster mushrooms given the unmet market demand. Mushroom entrepreneurs also need technical assistance such as equipment, production factor, training, and incentive provision which aim to enhance the motivation of mushroom entrepreneurs in increasing production capacity.

\section{Human Resources Aspect}

In terms of the human resources aspect, the most important sub-criteria are the labors availability (0.538), labors skills (0.274), labors education (0.128) and labors sources $(0.060)$. The $\mathrm{CR}$ value of the HR factors is $0.06(\mathrm{CR}<0.1)$. The labors needed for processing oyster mushrooms require skills and expertise than a high educational level, while the availability of trained labors is difficult to find. The skills and expertise of the labors are very influential on the quality and quantity of products (Fatria, 2017). The quality of the human resources can be improved by increasing the managerial ability and motivation to develop the businesses (Akhmadi et al. 2016).

\section{Technology Aspect}

In terms of the technology aspect, the most important sub-criteria are readiness for technology adoption (0.434), technology suitability (0.280), cultivation technology (0.155), harvest technology (0.084) and post-harvest technology (0.047). The CR value of the technology factor is $0.04(\mathrm{CR}<0.1)$. Technology is one of the main means to achieve effective, efficient, and high productivity efforts (Fatria, 2017). Technological factors consideration is also in accordance with Masyahoro (2006) and Imelda (2018) opinion that technological readiness and quality factors greatly influence the development of the agricultural sector. Technology adoption readiness in utilizing OPEFB as the mushroom growing media such as ease of process, ease of obtaining raw materials and process continuity needs to be fulfilled properly. Mushroom cultivation technology widely used by farmers and mushroom entrepreneurs is in the traditional way and only relies on the experience of mushroom entrepreneurs. This is due to the lack of readiness of business actors in adopting the technology. The lack of technology support can be seen from the limited research results related to mushroom production technology. Supporting Facilities Aspect. In terms of the supporting facilities aspect, the most important sub-criteria are the market $(0.541)$, road access (0.264), means of transportation (0.132), and means of communication (0.064). The CR value of the supporting facilities factors is $0.05(\mathrm{CR}<0.1)$. This is in line with the researches of Jumna (2015), Santoso and Marimin (2001) and Oelviani (2013) which state that market criterion is the most important criterion in agricultural development. Mushrooms as foodstuffs are important enough for the public food needs, making the production should be increased for the national needs (Sugiarti, 2003). This is the reason why horticultural agriculture requires serious attention regarding aspects of production and marketing system development (Dimyati and Astarina, 2016). Based on this, it is very appropriate to put the market aspect as the highest aspect, considering that mushroom agribusiness production performance is closely related to market problems (Oelviani, 2013; Khoirunnisa et al. 2013).

\section{Synthesis Results}

Table 2 shows the conclusions of the priorities of all sub-criteria and sub- sub criteria related to the development of oyster mushroom agribusiness. The overall model inconsistency is 0.05 . The weight value of all 23 sub-criteria ranges from 0.003 to 0.541 . Market (0.541) is the most important sub-criteria to be considered in formulating the priority factor in the development of sustainable oyster mushroom agribusiness, followed by return on investment $(0.457)$ and investment value $(0.151)$. The weight value of all $20 \mathrm{sub}$ criteria ranges from 0.001 to 0.543 . Market demand (0.543) is the most important aspect to be considered in the development of oyster mushroom agribusiness, followed by labor availability (0.093) and Net Present Value/NPV (0.067). Based on the synthesis results, it can be said that the market, which is included in the supporting facilities criterion, becomes a priority factor. It is proven by the current total production capacity of $60 \mathrm{~kg}$ per day has not been able to meet the demand for white oyster mushrooms. It provides opportunities for mushroom entrepreneurs to enhance their sales by increasing production capacity to be able to meet existing demand. 
Table 2. Local and global weighting of criteria and sub-criteria

\begin{tabular}{|c|c|c|c|c|}
\hline Main Criteria & Weight & Sub Criteria/sub-sub criteria & Local weight & Global Weight \\
\hline \multirow[t]{7}{*}{ Ecology } & 0.056 & OPEFB potential & 0.523 & $0.035 *$ \\
\hline & & Climate Conditions & 0.126 & $0.126 *$ \\
\hline & & a. Temperature & 0.637 & $0.008 * *$ \\
\hline & & b. Humidity & 0.105 & $0.003 * *$ \\
\hline & & c. Rainfall & 0.089 & $0.001 * *$ \\
\hline & & Potential pest attack & 0.089 & $0.006 *$ \\
\hline & & Water sources & 0.261 & $0.018 *$ \\
\hline \multirow[t]{13}{*}{ Financial } & 0.232 & Investment value & 0.151 & $0.151 *$ \\
\hline & & a. The price of supporting tools & 0.167 & $0.004 * *$ \\
\hline & & b. The price of supporting tools & 0.833 & $0.022 * *$ \\
\hline & & Operating costs & 0.078 & $0.078 *$ \\
\hline & & a. Production input costs & 0.833 & $0.011 * *$ \\
\hline & & b. Operating costs & 0.078 & $0.002 * *$ \\
\hline & & Return on investment & 0.457 & $0.457 *$ \\
\hline & & a. Net Present value (NPV) & 0.543 & $0.067 * *$ \\
\hline & & b. Net B / C Ratio & 0.457 & $0.031 * *$ \\
\hline & & c. Internal Rate of Ratio (IRR) & 0.136 & $0.017 * *$ \\
\hline & & d. Payback Period (PP) & 0.070 & $0.009 * *$ \\
\hline & & Productivity & 0.041 & $0.006 * *$ \\
\hline & & Mushrooms Selling Price & 0.273 & $0.040 * *$ \\
\hline \multirow[t]{6}{*}{ Socio-culture } & 0.029 & Perception & 0.648 & $0.648 *$ \\
\hline & & a. Ease of implementation & 0.701 & $0.012 * *$ \\
\hline & & b. Suitability with needs & 0.193 & $0.003 * *$ \\
\hline & & c. Observability & 0.106 & $0.002 * *$ \\
\hline & & Mutual cooperation culture & 0.230 & $0.004 *$ \\
\hline & & Local wisdom & 0.122 & $0.002 *$ \\
\hline \multirow[t]{4}{*}{ Institution } & 0.043 & Capital & 0.543 & $0.027 *$ \\
\hline & & Instruction & 0.070 & $0.003 *$ \\
\hline & & Farmer group & 0.136 & $0.007 *$ \\
\hline & & Farmer tools & 0.252 & $0.013 *$ \\
\hline \multirow[t]{8}{*}{ Human Resources } & 0.148 & Labors skills & 0.274 & $0.047 *$ \\
\hline & & Labors availability & 0.538 & $0.093 *$ \\
\hline & & Education & 0.128 & 0.128 \\
\hline & & a. Formal & 0.008 & $0.022 * *$ \\
\hline & & b. Informal & 0.200 & $0.006 * *$ \\
\hline & & Labors source & 0.060 & $0.060 *$ \\
\hline & & a. From family & 0.833 & $0.010 * *$ \\
\hline & & b. Outside the family & 0.060 & $0.002 * *$ \\
\hline \multirow[t]{5}{*}{ Technology } & 0.096 & Post-harvest technology & 0.047 & $0.007 *$ \\
\hline & & Adoption readiness & 0.434 & $0.060 *$ \\
\hline & & Technology compatibility & 0.280 & $0.039 *$ \\
\hline & & Cultivation technology & 0.155 & $0.022 *$ \\
\hline & & Harvest technology & 0.084 & $0.012 *$ \\
\hline \multirow[t]{7}{*}{ Supporting facilities } & 0.396 & Market & 0.541 & $0.541 *$ \\
\hline & & a. Market demand & 0.637 & $0.135 * *$ \\
\hline & & b. Market distribution & 0.105 & $0.022 * *$ \\
\hline & & c. Market information & 0258 & $0.055 * *$ \\
\hline & & Road access & 0.264 & $0.066 *$ \\
\hline & & Means of transportation & 0.132 & $0.033 *$ \\
\hline & & Means of communication & 0.064 & $0.016 *$ \\
\hline
\end{tabular}

Note: $*$ is the global weight of sub-criteria; ${ }^{* *}$ is the global weight of sub-sub criteria 


\section{Sensitivity Analysis}

Actual results indicate that the supporting facilities aspect is the most important sub-criteria and market demand is the most important sub criteria in the development of oyster mushroom agribusiness (Figure 2 ). The sensitivity analysis in Figure 3 shows that the weight value changes of a criterion affect the changes in another criterion. The weight change of sociocultural criterion (last priority) from actual 0.029 to 0.299 will change this criterion to be the top priority with the ease of implementing mushroom business as the most considered sub criteria in the development of sustainable oyster mushroom agribusiness. Meanwhile, institution criterion becomes the last priority (Figure 3). Changes can be made to another criterion.

\section{Managerial Implications}

This research contributes greatly to the palm oil industry and the oyster mushroom industry. The priority decision in the use of OPEFB (ecological aspect), one of the solid wastes produced by palm oil processing plants, as the growing media for oyster mushrooms will have direct implications for the palm oil industry in overcoming environmental pollution problems. It also supports the application of the Zero Emissions concept, i.e. the utilization of generated wastes. The use of OPEFB as the mushroom growing media is still limited. Priority decision to improve the supporting facilities aspect (market) implicates the efforts to boost competitiveness and competitive advantage. Therefore, the most appropriate approach model is sustainability. The sustainability approach model proposed in the hierarchy model is easy to understand and more comprehensive in deciding the priority criteria in sustainable oyster mushroom agribusiness development. The application of the AHP model will make business actors create the calculation of priority weighting using multi-criteria. This research will guide academics in the future to use AHP in providing appropriate factors to help sustainable oyster mushroom agribusiness development. This paper will enable practitioners to comprehend and make the right decisions and conclusions for the oyster mushroom industry and business actors to achieve competitiveness.

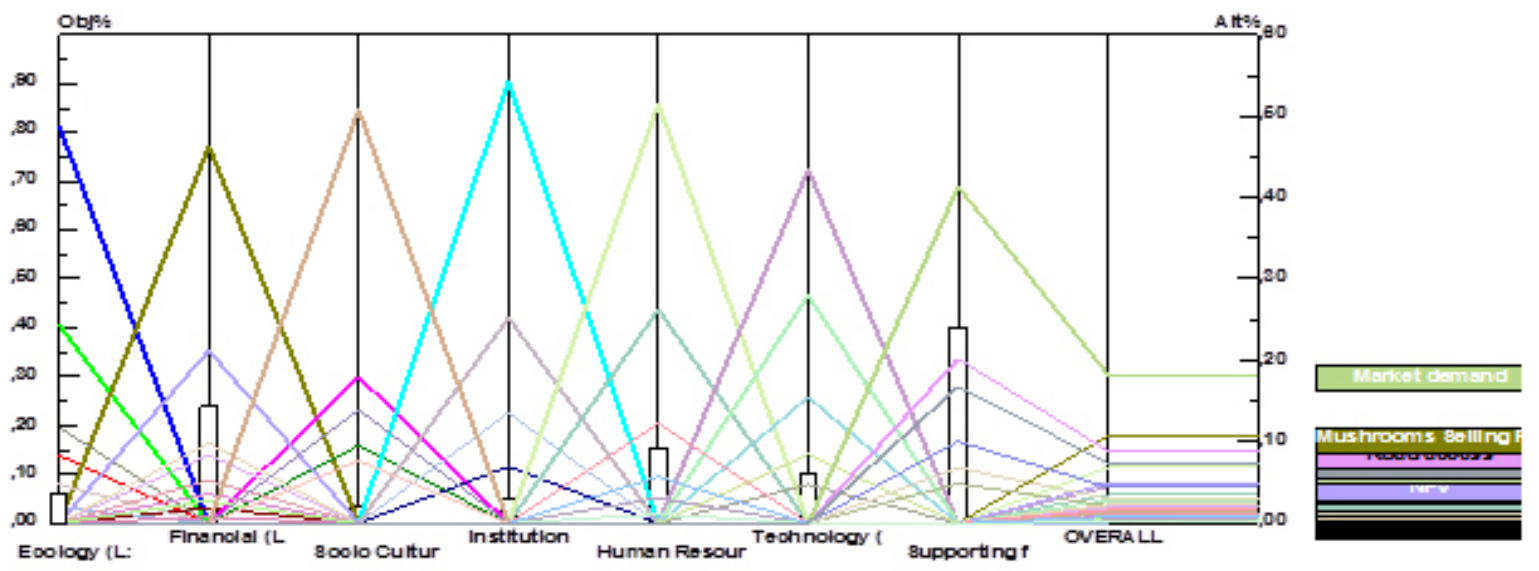

Figure 2. Hierarchy Model

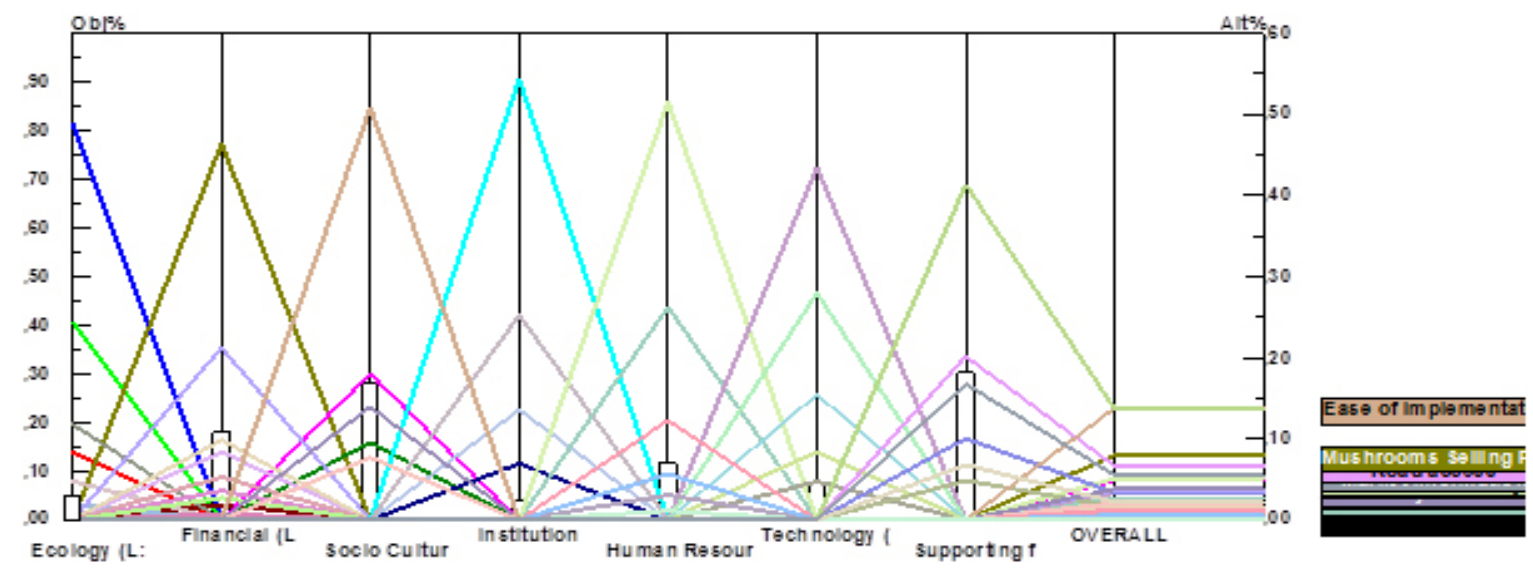

Figure 3. Latest results of sensitivity analysis 


\section{CONCLUSIONS AND RECOMMENDATIONS}

\section{Conclusions}

In this study, the priorities of the main criteria (ecology, financial, social culture, institution, human resources, technology, and supporting facilities) can be determined based on the current business scenario and the experts' judgment in the field. In detail, it can be concluded that the main priority is the supporting facilities aspect in the development of sustainable oyster mushroom agribusiness to achieve competitiveness. The priority of each criterion is OPEFB potential as the mushroom growing medium for ecology criterion, return on investment for financial criterion, perception and attitudes of society for socio-culture criterion, capital for institution criterion, labors availability for human resources criterion, technology adoption readiness for technology criterion, and the market for supporting facilities criterion. The synthesis results conclude that market demand is the most important sub-criteria. The demand management for oyster mushrooms is important so that oyster mushroom agribusiness remains sustainable. Increased production capacity needs to be done to meet the increasing demand for oyster mushrooms. Sensitivity analysis helps in understanding the extent to which priority changes in a criterion affect another criterion. Decision makers assist in determining decisions based on the present situation so that the chosen priority is more flexible and sustainable because it is adapted to the existing changes in the field. Sensitivity analysis helps in understanding the extent to which priority changes to a criterion affect another criterion.

\section{Recommendations}

The government's support in the form of technical assistance, training, and incentive provisions for business actors is needed to increase the motivation of business actors. Oyster mushroom production capacity is still low, while market demand continues to increase, making it is necessary to develop oyster mushroom agribusiness. In the future, this research is expected to highlight the different sides of each stakeholder's interests (business actors, governments, palm oil companies) by exploring what can lead to criteria, subcriteria, and sub-sub criteria in the overall hierarchical model.

\section{ACKNOWLEDGEMENT}

The author would like to acknowledge the support provided by the Ministry of Technology and Higher Education Research for funding this research through the skim of The Masterplan for Acceleration and Expansion of Indonesia\&\#39;s Economic Development (MP3EI).

\section{REFERENCES}

[BPS] Badan Pusat Statistik. 2016. Statistik Tanaman Sayuran dan Buah-Buahan Semusim Indonesia. Jakarta: BPS.

[BPS] Badan Pusat Statistik. 2017. Konsumsi Buah dan Sayur Susenas Maret 2016. Jakarta: BPS.

[BPS] Badan Pusat Statistik. 2017b. Provinsi Kalimantan Barat dalam Angka. Jakarta: BPS.

[Pusdatin] Pusat Data dan Sistem Informasi Pertanian. 2017. Statistik Ekonomi Pangan. Jakarta: Pusdatin Kementerian Pertanian.

Aji AA, Satria A, Hariono B. 2014. Strategi pengembangan agribisnis komoditas padi dalam meningkatkan ketahanan pangan di kabupaten Jember. Jurnal Manajemen dan Agribisnis 11(1):60-67.

Akhmadi, SiregarH,HutagaolMP. 2016. Pengembangan agribisnis sebagai strategi penanggulangan kemiskinan di perdesaan. Jurnal Manajemen dan Agribisnis 13(3):240-253. https://doi. org/10.17358/jma.13.3.240.

Amini MT, Keshavarz E, Keshavarz A, Bagheri SM. 2016. Proritisation and performance evaluation of employees at strategic human resource management process using fuzzy AHP and fuzzy TOPSIS. International Journal of Productivity and Quality Management 17(1):61-81. https:// doi.org/10.1504/IJPQM.2016.073275.

Azizi M, Mohebbi N, Gargari RM, Ziaie M. 2015. A strategic model for selecting the location of furniture factories: a case of the study of furniture. International Journal of Multicriteria Decision Making 5(1/2):87-108. https://doi.org/10.1504/ IJMCDM.2015.067939.

Candra R, Hepiana DA, Situmorang S. 2014. Analisis usahatani dan pemasaran jamur tiram dengan cara konvensional dan jaringan (multi level marketing) di provinsi lampung. JIIA 2(1):3847. 
Chiang FFT, Birtch TA. 2010. Pay for performance and work attitudes: the mediating role of employeeorganization service value congruence. International Journal of Hospitality Management 29(4):632-640.https://doi.org/10.1016/j. ijhm.2009.11.005.

Chioza A, Ohga S. 2014. Cultivated mushrooms in Malawi: a look at the present situation. Advances in Microbiology 4: 6-11.https://doi.org/10.4236/ aim.2014.41002.

Copra S, Meindl P. 2004. Supply Chain Management: Strategy, Planning and Operation, 2nd edition, New Jersey:Prentice Hall.

Dimyati L, Astarina Y. 2016. Strategi pengembangan usaha jamur tiram putih di kota Pagaralam. Prosiding Seminar Nasional Teknologi Informasi, Bisnis, dan Desain; 12 Mei 2016. STMIK Politeknik PalCom Tech. hlm 22-30.

Fatria MA. 2017. Strategi pengembangan industri rumahtangga di kota Pekanbaru (studi kasus usaha jamur crispy industri pengolahan jamur tiram). Jurnal Online Mahasiswa Fakultas Ekonomi 4(1):283-297.

Febrianda R, Tokuda H. 2017. Strategy and innovation of mushroom business in rural area Indonesia: case study of a developed mushroom enterprise from Cianjur district, West Java, Indonesia. International Journal of Social Science Studies 5(6):21-29.https://doi.org/10.11114/ijsss. v5i6.2304.

Hendra S, Hariyadib, Thoharic M. 2014. Analisis pengelolaan lingkungan pabrik kelapa sawit Batu Ampar-PT.SmartdalamimplementasiIndonesian sustainable palm oil. Jurnal Pengelolaan Sumberdaya Alam Dan Lingkungan 4(2):136144. https://doi.org/10.19081/jps1.2014.4.2.136.

Hermina, Prihatini S. 2016. Gambaran konsumsi sayur dan buah penduduk Indonesia dalam konteks gizi seimbang: analisis lanjut survei konsumsi makanan individu (SKMI) 2014. Buletin Penelitian Kesehatan 44(3):205-218. https:// doi.org/10.22435/bpk.v44i3.5505.205-218.

Hidayati, Hidayat MR, Asmawit. 2015. Pemanfaatan serat tandan kosong kelapa sawit sebagai media pertumbuhan jamur tiram putih. Biopropal Industri 6(2):73-80.

Imelda. 2018. Development strategy of agricultural sector for support the economy activities in border areas of West Kalimantan. Jurnal Aplikasi Manajemen 16(2):321-329. https://doi. org/10.21776/ub.jam.2018.016.02.15.
Imelda I, Kusrini N, Hidayat R. 2017. Development strategy of local food diversification. JEJAK: Jurnal Ekonomi dan Kebijakan 10(1):62-79

Indrajit ER, Djokopranoto R. 2003. Konsep Manajemen SC. Strategi Mengelola Manajemen Rantai Pasokan bagi Perusahaan Modern di Indonesia. PT. Gramedia Widiasarana.

Iriantinah C. 2014. Strategi pengembangan komoditas jamur tiram putih (pleurotus florida) di kabupaten Nganjuk. Jurnal Manajemen Agribisnis 14(2): 161-172.

Jumna B K, 2015. Strategi pengembangan usahatani dalam upaya peningkatan produksi padi organik di kecamatan Sambirejo kabupaten Sragen. Economics Development Analysis Journal 4(3):256-264.

Kashmir, Jakfar. 2008. Studi Kelayakan Bisnis. Ed.2. Jakarta: Kencana Prenada Media Group.

Kavitha B, Rajannan P, Jothimani. 2013. Utilization of empty fruit bunch of oil palm as alternate substrate for the cultivation of mushroom. International Journal Of Science, Environment and Technology 2(5):839-846.

Khoirunnisa A, Haryono D, Nugraha A. 2013. Analisis pendapatan dan pengambilan keputusan dalam menentukan tanaman sayuran unggulan di kecamatan Gisting kabupaten Tanggamus. Jurnal Ilmu-Ilmu Agribisnis 1(2):98-104.

Kuncoro M. 2003. Metode Riset Untuk Bisnis dan Ekonomi. Jakarta: Erlangga.

Kusrini N, Sulistiawati R, Imelda. 2017. Management strategy of oil palm waste in environmental development efforts. Russian Journal of Agricultural and Socio Economic Sciences 7(67):184-194.https://doi.org/10.18551/ rjoas.2017-07.22.

Li M, Hu J. 2014. Study on survival strategies of farmers engage in small-scale household cultivation of edible mushrooms: take Shandong province as an example. Modern Economy 5:1092-1100. https://doi.org/10.4236/me.2014.512100.

Mabuza M, Ortmann G, Wale E. 2012. Collective action in commercial mushroom production: the role of social capital in the management of informal farmer groups in Swaziland. International Association of Agricultural Economics (IAAE) Triennial Conference. Brazil pp. 1-22.

Masyahoro. 2006. Analisis kebijakan pengembangan perikanan purse seine dengan metode Analytical Hierarchi Process (AHP) di Perairan Kabupaten Parigi Moutong. Jurnal Agroland 13(3):275- 
281.

Maulidina R, Murdiono WE, Nawawi M. 2015. Pengaruh umur bibit dan komposisi media tanam terhadap pertumbuhan dan hasil jamur tiram putih (pleurotus ostreatus). Jurnal Produksi Tanaman 3(8):649-657.

Munizu M. 2017. Pengaruh kepercayaan, komitmen, dan teknologi informasi terhadapi kinerja rantai pasokan (studi kasus IKM pengolah buah markisa di kota Makassar). Jurnal Manajemen dan Agribisnis 14(1):32-42. https://doi. org/10.17358/jma.14.1.32.

Nurmalina, Sarianti, Karyadi. 2009. Studi Kelayakan Bisnis. Bogor: Fakultas Ekoonmi dan Manajamen Institut Pertanian Bogor.

Oelviani R. 2013. Penerapan metode Analytic Hierarchy Process untuk merumuskan strategi penguatan kinerja sistem agribisnis cabai merah di kabupaten Temanggung. Jurnal Informatika Pertanian 22(1):11-19. https://doi.org/10.21082/ ip.v22n1.2013.p11-19.

Olisa YP, Kotingo KW. 2014. Utilization of palm empty fruit bunch (POPEFB) as solid fuel for steam boiler. European Journal of Engineering And Technology 2(2):1-7.

Ongoche IC, Otieno DJ, Kosura WO. 2017. Assessment of factors influencing smallholder farmers' adoption of mushroom for livelihood diversification in Western Kenya. African Journal of Agricultural Research 12(30):2461-2467. https://doi.org/10.5897/AJAR2017.12397.

Palamae S, Dechatiwongse P, Choorit W, Chisti Y, Prasertsan P. 2017. Cellulose and hemicellulose recovery from oil palm empty fruit bunch (OPEFB) fibers and production of sugars from the fibers. Carbohydrate Polymers 155:491-497. https://doi.org/10.1016/j.carbpol.2016.09.004.

Pramudya FN, Cahyadinata I. 2012. Analisis usaha budidaya jamur tiram putih (pleurotus ostreatus) di kecamatan Curup Tengah kabupaten Rejang Lebong. Jurnal Agrisep (Kajian Masalah Agribisnis dan Sosial Ekonomi Pertanian) 11(2):237-250.https://doi.org/10.31186/ jagrisep.11.2.237-250.

Purindraswari R, Udiantoro, Agustina L. (2016). Pemanfaatan tandan kosong kelapa sawit sebagai media pertumbuhan jamur merang (volvariella volvacea) dalam upaya diversifikasi pangan. Seminar Nasional Lahan Basah. Universitas Lambung Mangkurat pp. 908-912.
Rahmawati N, Hasanuddin, Rosmayati. 2016. Budidaya dan pengolahan jamur merang (volvariella volvaceae) dengan media limbah jerami. Abdimas Talenta 1(1):58-63.

Saad SM, Kunhu N, Mohamed AM. 2016. A fuzzyAHP multi-criteria decision-making model for procurement process. International Journal Logistics Systems and Management 23(1):1-24.

Santoso I, Marimin, 2001. Penentuan produk olahan apel unggulan menggunakan teknik fuzzy non numerik dan analisis struktur serta pola pembinaan kelembagaannya. Jurnal Teknologi dan Industri Pangan 12(2):163-170.

Sekaran U, Bougie R. 2010. Research Method for Business A Skill Building Approach (5 ed.). United Kingdom: John Wiley and Sons Ltd.

Setyaningsih A, Zaenab S, Hudha AM. 2015. Pengaruh Penambahan Tepung Tongkol Jagung Pada Media Tanam Terhadap Berat Basah Jamur Tiram Putih (Pleurotus ostreatus) Sebagai Bahan Ajar Biologi. Prosiding Seminar Nasional Pendidikan Biologi; Malang, 21 Maret 2015. Malang: Universitas Muhammadiyah Malang hlm. 403-409.

Sugiarti S. 2003. Usaha tani dan pemasaran cabai merah di kabupaten Rejang Lebong. Jurnal Akta Agrosia 6(1):30-34.

Sulistiawati R, Kusrini N, Imelda. 2017. Analisis Finansial Usaha Pemanfaatan Limbah Tandan Kosong Kelapa Sawit. Prosiding Seminar Nasional Penerapan Ilmu Pengetahuan dan Teknologi; Pontianak, 23-24 Mei 2017. Pontianak: Universitas Tanjungpura.

Sumarni. 2006. Botani dan tinjauan gizi jamur tiram putih. Innofarm: Jurnal Inovasi Pertanian 4(2):124-130.

Sumiati E, Shopa GA. 2009. Aplikasi jenis bahan baku dan bahan aditif terhadap kualitas bibit induk jamur shiitake. Jurnal Hortikultura 19(1):49-58.

Sutarman. 2012. Keragaan dan produksi jamur tiram putih (pleurotus ostreatus) pada media serbuk gergaji dan ampas tebu bersuplemen dedak dan tepung jagung. Jurnal Penelitian Pertanian Terapan 12(3):163-168.

Tabi, Zakil, Fauzai, Ali, Hasan. 2008. The usage of empty fruit bunch (OPEFB) and palm pressed fibre (PPF) as substrates for the cultivation of pleurotus ostreatus. Jurnal Teknologi 49(F):189196. 